\title{
Potensi Buah Nipah Tua (Nypa Fruticans Wurmb) Sebagai Bahan Pakan Ternak
}

\author{
Khalil dan T. Hidayat \\ Jurusan Ilmu Nutrisi dan Makanan Ternak Fakultas Peternakan \\ Universitas Andalas Padang
}

\begin{abstract}
A field survey has been conducted to study the potency of fruit of palm grown in West Sumatra for animal feedstuff. Three coastal areas which were identified as most populated palm plant in West Sumatra were selected as study sites, i.e., Padang city and the districts of Padang Pariaman and Pesisir Selatan. Five clusters of palm were randomly selected in each selected site and then bunches of their fruit were identified. The bunches were divided into 4 groups based on maturity status: very young, young, mature and old fruit bunches. The old fruits were then harvested, weighed and processed to separate their endosperm part. After weighing, the endosperm were then dried and ground for chemical analysis. Parameters measured included: number of bunch, old fruit and their endosperm weigh, nutrient content of endosperm. The data were statistically analysis for variance analysis in completely block design with 3 treatments and 3 blocks as replicates. Results shown that the highest number of bunches was found by the old fruit (6.7 bunches/cluster), followed by the very young fruits (2.7), mature fruit (1.7) and young fruit (1.5). About $22 \%$ of old fruit consisted of endosperm part. The endosperm contains about $16 \%$ crude protein, very low crude fat of $0.6 \%$, but considerably high crude fiber of about $50.5 \%$.
\end{abstract}

Key words: palm, old fruit, endosperm, nutrient content.

Pendahuluan

Nipah (Nypa fruticans Wurmb) termasuk keluarga tanaman palem (palmae). Tanaman ini biasa tumbuh di daerah pantai di muara sungai yang berair payau. Propinsi Sumatera Barat memiliki hutan nipah yang cukup luas dan tersebar di sepanjang pantai dan muara sungai Samudra Hindia. Tanaman ini tersebar mulai dari pantai bagian utara, dari pantai Air Bangis (Kabupaten Pasaman Barat), Kabupaten Padang Pariaman, Kecamatan Tanjung Mutiara (daerah Tiku) (Kabupaten Agam), Kota Padang, sampai kebagian selatan, yaitu pantai
Kabupaten Pesisir Selatan dan kepulauan Mentawai.

Tanaman nipah tumbuh secara alamiah dan dari aspek ekologis bermanfaat untuk melindungi bibir pantai dari proses abrasi oleh gelombang laut dan juga sebagai tempat bersarangnya ikan, burung dan biota lain yang biasa hidup di perairan pantai. Pemanfaatan oleh masyarakat masih terbatas oleh penduduk yang bermukim disekitar pantai untuk keperluan hidup sehari - hari. Bagian tanaman yang dimanfaatkan misalnya pelepah untuk kayu bakar, daun untuk atap rumah dan tulang daun untuk sapu lidi. 
Tanaman nipah juga menghasilkan buah yang dapat dimanfaatkan. Menurut Rahman dan Sudarto (1990) buah nipah yang terhimpun dalam bentuk tandan dibagi atas 4 kelompok berdasarkan perkembangannya. Pertama buah putik, yaitu buah yang masih berukuran sangat kecil, sebesar kelereng. Kedua buah muda, yaitu buah yang sedang aktif menimbun cadangan makanan dalam bentuk gula di dalam bakal buah. Tandan buah ini biasanya disadap oleh masyarakat untuk mendapatkan air nira atau untuk pembuatan gula aren. Ketiga buah matang, yaitu buah yang mengandung isi yang bertekstur liat, berwarna putih seperti agar. Daging buah ini terasa manis dan biasa digunakan oleh masyarakat untuk membuat bahan makanan yang dikenal dengan kolang - kaling. Keempat buah tua, yaitu buah yang sudah cukup umur dan terasa ringan. Kulitnya keras dan biasanya berwarna coklat tua sampai kehitaman. Buah inilah yang biasanya banyak terbuang dan sulit untuk dimanfaatkan, karena bagian kulitnya terlalu tebal dan keras.

Jika dilakukan observasi lapang ke hutan nipah di pesisir pantai di Sumatera Barat, banyak terlihat tandan - tandan dengan buah yang sudah tua menggantung atau terendam air pasang yang ratusan jumlahnya. Buah nipah tua ini hanya dibiarkan sampai rontok sendiri dan kemudian hanyut terbawa arus tanpa termanfaatkan. Padahal pada bagian dalam buah terdapat daging buah (mesocarp) yang terbungkus oleh kulit berupa sabut berwarna coklat, keras dan liat. Daging buah yang berwarna putih dan berbentuk bulat panjang tersusun atas karbohidrat berupa pati dan gula yang mudah dicerna dan mempunyai nilai gizi tinggi untuk bahan pangan dan pakan.

Penelitian dilakukan dengan tujuan untuk mempelajari potensi buah nipah, terutama buah yang tua, sebagai bahan pakan. Potensi yang diteliti termasuk: jumlah buah tua, rendemen isi dan kandungan zat makanan.

\section{Materi Dan Metode}

\section{Lokasi dan Pengambilan Contoh}

Penelitian dilakukan melalui pengambilan contoh buah nipah pada 3 lokasi yang berbeda, yaitu di daerah pantai di Kota Padang (kelurahan Padang Sarai, Kecamatan Koto Tangah), Kabupaten Padang Pariaman (Desa Ketaping, Kecamatan Batang Anai) dan Kabupaten Pesisir Selatan (Desa Api - api, Kecamatan Bayang).

Pada setiap lokasi dipilih secara acak 5 (lima) rumpun nipah dengan mempertimbangkan: jarak, umur tanaman dan kemudahan dijangkau. Pada setiap rumpun tanaman yang terpilih dilakukan penghitungan dan pencatatan jumlah tandan yang dominan buah: putik, muda, matang dan tua. Tandan buah tua kemudian dipotong dan ditimbang beratnya. Buah kemudian dirontokkan dari tandan dan dipisahkan antara buah berisi dan yang buah kosong. Buah tua yang berisi selanjutnya dibagi menjadi 3 kelompok berdasarkan ukuran: besar, sedang dan kecil. Jumlah setiap kolompok dihitung dan ditimbang beratnya.

Selanjutnya, bagian isi dipisahkan dari kulit dan ditimbang berat segarya. Isi kemudian dikeringkan dengan cara dijemur dibawah sinar matahari. Isi yang sudah kering kemudian ditimbang dan selanjutnya digiling untuk dianalisa kandungan zat makanannya. 


\section{Parameter yang Diukur}

Parameter yang diukur antara lain: rataan jumlah tandan buah per rumpun, jumlah total buah tua (butir/tandan), rataan berat buah tua (g/butir), rataan berat isi ( $\mathrm{g} /$ butir), rendemen isi (\%) dan kandungan zat makanan, yaitu: air, bahan kering (BK), protein kasar, lemak kasar dan serat kasar.

\section{Analisis Statistik}

Data hasil penelitian dianalisis secara statistik melalui analisa keragaman dengan rancangan acak kelompok (RAK), terdiri atas 3 perlakukan dan 3 kelompok sebagai ulangan (Steel and Torrie, 1980).

\section{Hasil Dan Pembahasan}

Jumlah Tandan dan Buah Tua serta Rendemen Isi

Pada Tabel 1 disajikan data rataan jumlah tandan dari empat kelompok buah berdasarkan perkembangannya. Jumlah total tandan berkisar antara 9,4 - 15,4 tandan/ rumpun, dimana jumlah tandan terbanyak ditemukan pada tanaman nipah yang tumbuh di daerah Pesisir Selatan. Dari jumlah tandan yang ada, tandan buah yang dominan adalah tandan buah tua, rata - rata 6,7 tandan/ rumpun dengan kisaran antara 4,8 7,2 tandan per rumpun, diikuti oleh tandan buah putik, rata - rata 2,7 tandan/rumpun (1,2 - 4,2 tandan/ rumpun). Sedangkan jumlah tandan yang paling rendah terlihat pada tandan buah muda, 1,5 tandan/rumpun (1,2 - 2,0 tandan/rumpun). Data ini menunjukkan bahwa diantara ke empat kelompok buah yang ada, buah nipah tua yang paling banyak ditemukan. Salah satu faktor penyebabnya diduga buah tua ini belum dimanfaatkan oleh masyarakat.

Jika dilihat dari lokasi tumbuhnya, nipah yang tumbuh di daerah Pesisir Selatan menunjukkan jumlah total tandan tertinggi (15,4 tandan/ rumpun), nyata lebih tinggi jika dibandingkan dengan jumlah tandan nipah yang tumbuh di daerah pantai Kota Padang (9,4 tandan/rumpun) dan Kabupaten Padang Pariaman (11,2 tandan/rumpun).

Tabel 1. Rataan Jumlah Tandan per Rumpun (tandan/rumpun)

\begin{tabular}{cccccc}
\hline \multirow{2}{*}{ No. } & \multirow{2}{*}{ Parameter } & Padang & $\begin{array}{c}\text { Padang } \\
\text { Pariaman }\end{array}$ & $\begin{array}{c}\text { Pesisir } \\
\text { Selatan }\end{array}$ & Rataan \\
\cline { 3 - 5 } 1 & Tandan Putik & $2,6^{\mathrm{a}}$ & $1,2^{\mathrm{a}}$ & $4,2^{\mathrm{b}}$ & $2,7^{* *}$ \\
2 & Tandan Muda & 1,2 & 1,4 & 2,0 & $1,5^{\mathrm{ns}}$ \\
3 & Tandan Matang & $0,8^{\mathrm{n}}$ & 1,4 & 2,8 & $1,7^{\mathrm{ns}}$ \\
4 & Tandan Tua & $4,8^{\mathrm{n}}$ & $7,2^{\mathrm{n}}$ & 6,4 & $6,7^{\mathrm{ns}}$ \\
\hline & J u m l a h & $9,4^{\mathrm{a}}$ & $11,2^{\mathrm{a}}$ & $15,4^{\mathrm{b}}$ & $12,6^{* *}$ \\
\hline
\end{tabular}


Sedangkan jumlah tandan tua terbanyak ditemukan pada nipah yang tumbuh di daerah pantai Padang Pariaman (7,2 tandan/rumpun), tetapi tidak berbeda nyata secara statistik dengan jumlah tandan tua yang terdapat pada nipah yang tumbuh di pantai Kota Padang (4,8 tandan/ rumpun) dan Pesisir Selatan (6,4 tandan/rumpun).

Secara umum, buah nipah yang banyak dimanfaatkan oleh masyarakat adalah buah yang matang, sedangkan buah putik, muda dan tua tidak dimanfaatkan. Sulitnya membedakan antara buah yang muda dengan yang matang menyebabkan rataan jumlah tandan buah yang muda menjadi lebih rendah. Buah yang muda pada tandannya seringkali terbuang sia sia, akibat metode coba - coba yang dilakukan masyarakat dalam pemanenan buah matang. Oleh sebab itu, tandan buah yang matang yang seharusnya rataanya lebih rendah, didominasi oleh tandan buah yang muda dan ini terbukti dengan tidak jauhnya selisih rataan dari kedua tandan nipah itu (0,2 tandan/rumpun) (Tabel 1).

Meskipun secara statistik tidak berbeda nyata, tingginya rataan tandan buah tua yang tumbuh di daerah pantai Padang Pariaman disebabkan lokasinya yang amat terpencil, sehingga buah nipah disini jarang disentuh oleh manusia. Sebaliknya, jumlah tandan tua yang paling rendah ditemukan di pantai Kota Padang, karena dekatnya lokasi tempat tumbuh nipah dengan pemukiman penduduk, sehingga buah ini mungkin banyak dipanen oleh masyarakat sekitar sebelum menjadi tua.

Pada Tabel 2 disajikan data rataan jumlah buah tua dan rendemen isinya. Rataan jumlah buah tua sekitar 15,2 butir/tandan, dimana jumlah terbanyak (17,8 butir/tandan) ditemukan pada tanaman nipah yang tumbuh di daerah pantai Padang Pariaman, tetapi secara statistk tidak berbeda nyata $(P>0,05)$ dengan jumlah buah tua dari tanaman yang tumbuh di Padang (16,2 butir/tandan) dan Pesisir Selatan (11,5 butir/tandan). Tingginya rataan jumlah buah nipah tua yang tumbuh di daerah pantai Padang Pariaman dan Padang disebabkan didaerah ini dalam setiap tandan buah nipah lebih sedikit terdapat buah yang tidak berisi (hampa), sedangkan di daerah Pesisir Selatan pada setiap tandannya lebih banyak terdapat buah hampa.

Rataan bobot buah tua utuh, bobot isi dan rendemen masingmasing sekitar 93,5 g/butir, 21,2 g/butir dan 22,4 \% dari bobot utuh, dimana tidak terdapat perbedaan yang nyata dari ke tiga parameter ini diantara tiga lokasi yang berbeda. Nilai rataan rendemen ini mempunyai hubungan yang erat dengan berat utuh dan berat isi. Meskipun tidak berbeda secara statistik, rataan rendemen isi yang paling rendah ditemukan pada nipah yang tumbuh di daerah Pesisir Selatan (20,5\%), sedangkan berat utuh dan berat isi buah nipah yang tua yang paling rendah ditemukan pada daerah yang sama (masing - masing 81,7 dan 18,3 g/butir). Hal ini disebabkan tandan buah di Pesisir Selatan ini memiliki buah yang kecilkecil, kurang produktif dan ini terlihat dengan rendahnya rataan jumlah buah (11,5 butir/tandan), rataan berat utuh (81,7 g/butir), berat ini (18,3 g/butir) dan rendemen isi $(20,5 \%)$ (Tabel 2). 
Tabel 2. Rataan Jumlah Buah Tua dan Rendemen Isi

\begin{tabular}{llcccc}
\hline \multirow{2}{*}{ No. } & \multicolumn{1}{c}{ Parameter } & Lokasi tumbuh & \multirow{2}{*}{ Rataan } \\
\cline { 3 - 5 } & & 16,2 & 17,8 & 11,5 & $15,2^{\mathrm{ns}}$ \\
\hline 1 & $\begin{array}{l}\text { Jumlah Buah Tua } \\
\text { (butir/tandan) }\end{array}$ & 110,6 & 88,2 & 81,7 & $93,5^{\mathrm{ns}}$ \\
2 & Berat Utuh (g/butir) & 22,4 & 22,5 & 18,3 & $21,1^{\mathrm{ns}}$ \\
3 & Berat Isi (g/butir) & 20,8 & 26,0 & 20,5 & $22,4^{\mathrm{ns}}$ \\
4 & $\begin{array}{l}\text { Rendemen Isi (\% Berat } \\
\text { Utuh) }\end{array}$ & & & & \\
\hline
\end{tabular}

Tabel 3. Rataan Kandungan Zat Makanan Bagian Isi Buah Nipah Tua (\% BK)

\begin{tabular}{|c|c|c|c|c|c|}
\hline \multirow[b]{2}{*}{ No. } & \multirow[b]{2}{*}{ Parameter } & \multicolumn{3}{|c|}{ Lokasi Tumbuh } & \multirow[b]{2}{*}{ Rataan } \\
\hline & & Padang & $\begin{array}{c}\text { Padang } \\
\text { Pariaman }\end{array}$ & $\begin{array}{l}\text { Pesisir } \\
\text { Selatan }\end{array}$ & \\
\hline 1. & Protein Kasar & 16,1 & 18,3 & 18,0 & $17,5^{\mathrm{ns}}$ \\
\hline 2. & Lemak Kasar & $0,7^{\mathrm{a}}$ & $0,9^{b}$ & $0,5^{\mathrm{a}}$ & $0,7^{*}$ \\
\hline 3. & Serat Kasar & 61,8 & 58,1 & 48,1 & $56,0^{\mathrm{ns}}$ \\
\hline
\end{tabular}

Rataan rendemen isi buah tua yang paling tinggi ditemukan pada nipah yang tumbuh di daerah Padang Pariaman $(26 \%)$ dengan rataan berat ini juga yang paling tinggi $(22,5$ g/butir). Sedangkan rataan berat buah dalam keadaan utuh paling tinggi ditunjukkan oleh nipah yang tumbuh di daerah pantai Kota Padang (110,6 g/butir). Hal ini disebabkan buah nipah di daerah ini ukuruan lebih besar dan pada saat pemotongan tandan, tandan - tandan buah banyak yang terendam air pasang.

\section{Kandungan Zat Makanan}

Pada Tabel 3 disajikan data rataan kandungan zat makanan isi buah nipah yang sudah tua. Rataan kadungan bahan kering isi sekitar 69 $\%$, dengan variasi yang cukup besar, yaitu antara 57,5 sampai 83,2 \%. Besarnya variasi ini disebabkan faktor kondisi bahan saat dipanen, dimana adanya sebagian tandan buah yang terendam air pasang. Buah yang terendam air pasang ini menunjukkan kandungan bahan kering yang rendah.

Isi buah nipah mengandung protein kasar sekitar 17,5 \%. Kandungan lemak sangat rendah, yaitu sekitar $0,7 \%$, tetapi kandungan serat kasar cukup tinggi, yaitu sekitar $56 \%$. Kandungan protein dan serat kasar tidak banyak dipengaruhi oleh lokasi tumbuh tanaman.. Jika dibandingkan dengan bungkil dari buah tanaman palem lainnya, kandungan protein isi buah nipah setara dengan bungkil kelapa sawit, bungkil kelapa dan ampas kelapa, tetapi kandungan seratnya jauh lebih tinggi dan kandungan lemaknya lebih rendah. Bungkil kelapa sawit dan bungkil kelapa mengandung protein dan serat kasar masing - masing sekitar: 15,0 dan $19,7 \%$ serata 21,6 dan $12,1 \%$ (Hartadi et al., 1990). 
Jika dilihat dari kandungan lemaknya, maka isi buah nipah yang sudah dikeringkan relatif tahan untuk disimpan lama. Sedangkan jika dilihat dari kandungan protein dan serat, isi buah nipah sebaiknya diberikan pada ternak unggas yang relatif toleran terhadap makanan yang mengandung serat tinggi, seperti itik.

\section{Kesimpulan}

Dari hasil penelitian dapat ditarik kesimpulan bahwa buah nipah tua merupakan jumlah terbanyak dari buah yang terdapat pada tanaman nipah. Buah tua ini berpotensi digunakan sebagai bahan pakan, terutama sebagai bahan sumber energi dalam ransum. Isi buah nipah mengandung protein sekitar 17,5\%, lemak $0,7 \%$ dan serat kasar 56,0 \%.

\section{Daftar Pustaka}

Hartadi, H., S. Reksohadiprodjo dan A.D. Tillman, 1990. Tabel Komposisi Pakan Untuk Indonesia. Gadjah Mada University Press.

Rahman, A. Dan Y. Sudarto, 1991. Nipah Sember Pemanis Baru. Penerbit Kanisius, Jakarta.

Steel, R.G.D. and J.H. Torrie, 1980. Principles and Procedures of Statistics. McGraw-Hill Inc., NY.

Alamat Korespondensi: Dr. Ir. Khalil, M.Sc. Jurusan Ilmu Nutrisi dan Makanan Ternak Fakultas Peternakan Universitas Andalas Liamau Manis, Padang Telp.: 0752-498162, HP: 08126611691

Artikel diterima: 2 Mei 2006, disetujui 29 Mei 2006. 